\title{
Exposure to excessive oral vitamin D in youth: a risk factor for celiac disease in later life?
}

Seth Bittker

Correspondence: sbittker@yahoo.com

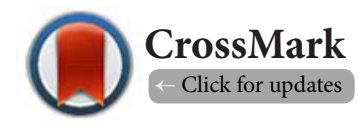

17 Edmond Street, Darien, Connecticut 06853, USA.

\begin{abstract}
Celiac disease is an autoimmune disease initiated by an allergic reaction to gliadin a component of the protein gluten that is found in wheat and other grains. Vitamin D is a prohormone with a number of biochemical functions including immunomodulatory functions in its active form. Supplementation with large doses of vitamin D induces symptoms that are similar to celiac disease in some of the population. Some researchers have noted that consumption of large doses of oral vitamin $\mathrm{D}$ early in life is associated with increased incidence of allergic diseases later in life. An examination of celiac disease suggests that an allergy is fundamental to its development and it features Th2 cytokine elevations which typically characterize allergic diseases. In addition it has comorbidity with allergic diseases where exposure to large doses of vitamin D early in life is a risk factor. This raises the possibility that large doses of vitamin D early in life could be a risk factor for inducing celiac disease later in life as well. The comorbidity between Williams syndrome, which is characterized by spikes in blood levels of vitamin $\mathrm{D}$, and celiac disease gives additional credence to this hypothesis. Epidemiological evidence supports this hypothesis as well. Vitamin D consumption among the young and celiac disease prevalence are high in Sweden, Finland, and the United States. Vitamin D consumption among the young and celiac disease prevalence are low in Russia and Germany. The timing of the increases in prevalence in the United States and Sweden also coincides with increasing vitamin D consumption. This is most striking in Sweden where a law required significant vitamin D fortification of food starting in 1983 and the start of the celiac epidemic in Sweden has been independently dated from 1984. This hypothesis also provides a potential explanation for some seemingly contradictory results in the literature regarding breastfeeding and risk of celiac disease.
\end{abstract}

Keywords: Th2, allergy, allergic, immunology, milk, formula

\section{Introduction}

Celiac disease is an autoimmune disease of the small intestine initiated by an allergy to gliadin which is a component of the protein gluten found in wheat and some other grains [1]. There is significant variability in the estimates of prevalence of celiac disease, but as of 2012 one estimate was approximately $1 \%$ of the world-wide population [2], with significant variation between countries $[\mathbf{1 , 2}]$. Looking at similar cohorts over time shows that the prevalence of celiac has increased significantly in recent decades in some countries [3-5]. Ludvigsson and Green recently hypothesized that there is a "missing environmental factor in celiac disease" that is responsible for this increase [6].

Vitamin $D$ is a fat soluble vitamin that in its active form enhances calcium absorption, raises blood levels of calcium, and affects the immune system. It can be synthesized in the skin through sunlight and in this sense it is not a vitamin as enough can be synthesized from sunlight to promote good health. Vitamin D produced in this way will not result in toxicity due to self-regulating mechanisms. Vitamin D may also be absorbed orally, where there is no similar self-regulating absorption mechanism [7].

\section{Hypothesis}

\section{Biologic plausibility}

Celiac is typically characterized by atrophy of the intestinal villi and is frequently accompanied by abdominal pain, bloating, diarrhea, constipation, and sometimes weight-loss [8-10].

In rats where extremely high doses of oral vitamin $D$ have been tested ( $2 \mathrm{mg} / \mathrm{kg}$ per day orally), the digestive effects include 
diarrhea and sloughing of the intestinal villi [11]. In humans, accidental ingestion of high doses $(100,000 \mathrm{~s}$ of IU) of vitamin D sometimes causes digestive effects including constipation and weight-loss $[12,13]$. In human trials where high doses of vitamin $\mathrm{D}$ have been consumed, gastrointestinal effects have been significant. For example, in one trial of supplementation in women who were at risk of breast-cancer, in a cohort receiving 30,000 IU per week for one year, $9 \%$ experienced abdominal distension, $14 \%$ experience abdominal pain, $27 \%$ experienced constipation, $9 \%$ experienced diarrhea, and $18 \%$ experienced nausea. By comparison the only gastrointestinal complaint observed in a lower dose $(20,000$ IU) cohort was abdominal pain in $11 \%$ [14].

Yet even at more modest doses (400 IU per day and $700 \mathrm{IU}$ per day), some in human trials of vitamin $D$ supplementation have dropped out due to complaints of stomachache, diarrhea, or constipation $[15,16]$. In one trial of vitamin D supplementation among 171 girls in Finland one girl who started supplementing was not able to complete the trial due to the onset of celiac disease [17]. One may disregard this example alone as coincidental, but the other evidence above strongly suggests that large doses of vitamin D will cause effects that are similar to the symptoms of celiac disease in some of the population and hints of such effects occur at more modest doses.

Infants and toddlers in much of the developed world consume large amounts of vitamin D relative to that which is obtainable through natural sources. For example, total vitamin $D$ in human milk is about $45 \mathrm{IU}$ per liter and in unfortified cows' milk is about $40 \mathrm{IU}$ per liter $[\mathbf{1 8 , 1 9 ]}$. By comparison in the United States infant formula averages about 535 IU per liter, whole milk averages about $525 \mathrm{IU}$ per liter, the standard daily dose of vitamin $D$ drops recommended for breastfed infants starting at birth is $400 \mathrm{IU}$, and the most popular brand of children's multivitamin contains $600 \mathrm{IU}$ [20-23]. In addition substantial doses of vitamin $D$ are also present in fortified foods such

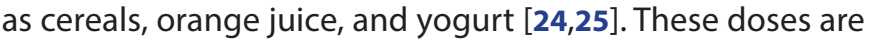
large by comparison to those available in human milk and provided at high frequency to infants and toddlers who are small by weight. If one assumes that the effects of a dose are proportional to IUs consumed per pound of weight, then a 10 pound infant receiving the standard $400 \mathrm{IU}$ per day dose via vitamin $D$ drops is equivalent to a 150 pound adult receiving 42,000 IU per week through supplementation. One need not make this simplifying and perhaps unjustified assumption to see that the doses given to infants and toddlers are large. So it seems likely that the aggressive vitamin $D$ supplementation and fortification which typically accompanies infancy in the United States will induce gastrointestinal effects in some infants and toddlers as seen in some adult trials and that these effects as already mentioned mirror many of the symptoms of celiac disease.

\section{Oral vitamin $\mathrm{D}$ as a risk factor for allergic disease} An allergic disease is a disease in which a hypersensitivity immune reaction is fundamental to its development [26]. The relationship between vitamin $D$ and allergic disease is complex [27]. Littonjua among others has suggested that low serum levels of 25-hydroxy vitamin $\mathrm{D}$ are a causative factor in allergic disease [28]. Yet Wjst has highlighted that both extremely low and extremely high serum levels of 25-hydroxy vitamin $D$ are associated with allergic disease [29]. For example while Baek et al., found that low serum levels are associated with atopic allergy in infancy [30], Heimbeck et al., found that children and adolescents with high serum levels had higher rates of atopic dermatitis than those with low vitamin $D$ serum levels [31], and Kang et al., found that 25-hydroxy vitamin D serum levels were correlated with dust mite allergy based on serum analysis [32].

Other research suggests that oral vitamin D supplementation in the young is associated with allergic disease in later life. For example Hypponen et al., found that oral vitamin D supplementation early in life is associated with higher rates of allergies, asthma, and atopic dermatitis in later life [33]. Nja et al., found that early life supplementation with cod liver oil and vitamins was associated with increased prevalence of allergic sensitization and asthma later in life [34]. Cod liver oil contains some vitamin D and supplemental vitamins often do as well. Back et al., also found that oral vitamin D supplementation in infancy results in greater prevalence of atopic allergies in later life [35]. Interestingly Kull et al., found that vitamin A and vitamin D supplementation in water-soluble form were much more likely to be associated with allergic disease in children than the same vitamins in peanut oil [36].

Wjst found that low levels of allergies among those in isolated rural communities in Bavaria could be explained by low levels of oral vitamin D consumption in those same communities [37]. In separate research Wjst provided evidence that allergic diseases were rare before the introduction of vitamin $D$ supplementation and suggested that oral vitamin $D$ is the key factor in the allergy pandemic that has engulfed the civilized world [38].

There is a strong theoretical basis for why large doses of oral vitamin D may induce allergic diseases in some as suggested by the empirical evidence. Th1 cells focus the immune system primarily on intracellular pathogens, while Th2 cells focus the immune system primarily on extracellular pathogens [39]. Consumption of oral vitamin D generally induces a Th2 skew to the immune system [40]. Therefore consumption of oral vitamin D will tend to elevate Th2 cytokine activity which will upregulate immune reactions to external stimuli. So it should not be surprising that allergic conditions typically feature elevated levels of Th2 cells. Among these are atopic dermatitis and asthma $[41,42]$.

Despite the empirical evidence outlined above and the theoretical rationale, other trials suggest that modest supplementation of oral vitamin $\mathrm{D}$ may decrease the risk of or ameliorate the symptoms of certain allergic diseases [43]. While this may seem contradictory it seems plausible that 
the effect of supplementation depends upon a number of factors including dosage, duration, age, weight, sunlight exposure, antigen exposure, past antigen exposure, stores of vitamin $D$ in the body, and maternal vitamin $D$ levels in utero. In addition vitamin $D$ has many effects on the immune system and they act over different timeframes. For example, vitamin D downregulates Th17 cell production which decreases the current levels of inflammation in some allergic diseases [44]. Yet vitamin D through Th2 cytokines upregulates production of $B$ cells that imprint on antigens and form enduring humoral immune memory [45]. So the effect of vitamin D supplementation in some circumstances may be an immediate decrease in inflammation through downregulation of Th17 while simultaneously inducing or reinforcing a lifelong allergy through $B$ cell upreguation. For this reason one would expect contradictory long term and short term effects in some allergic diseases from oral vitamin $D$ supplementation. In any case the evidence above suggests that oral vitamin D supplementation among the young increases the risk of allergic diseases over long time frames for some of the population via upregulation of Th2 cytokines.

\section{Celiac as a Th2 mediated allergic disease}

While celiac is often categorized as an autoimmune disease, an excessive immune reaction to the protein gliadin is fundamental to its development. In fact an IgA blood test for antibodies to gliadin is often the initial step in diagnosis [46]. So while it is not normally categorized as an allergic disease, it is an allergic disease based on the classical definition of allergy as an excessive immune reaction to external stimuli [47]. In fact Dietert et al., consider celiac to be primarily an allergic disease with an autoimmune component [48]. Interestingly while most have considered activation of Th1 cell cytokines to be of greater importance in celiac disease, it appears that elevations in Th2 cell cytokines are also fundamental to it. Lahat et al., found that both Th1 and Th2 cell cytokines are activated in celiac [49]. Manavalan et al., found higher levels of Th2 cell cytokines in those with celiac disease than controls and that those who had been on a gluten free diet less than a year had higher levels of Th2 cytokines than those who had been on a gluten free diet for more than a year [50]. Manavalan et al., commented that the role of Th2 cell "cytokines in [celiac] pathogenesis is not well understood, but immune regulatory functions at the mucosal level have been suggested" [50]. This suggestion was inferred from a study by Chowers et al., analyzing cytokine levels in colonic mucosa immediately following gluten challenge [51]. Separately Mastrandrea et al., found that among a group of 28 celiac patients all but three had a Th2 skew expressed in the chemokine receptor pattern of their circulating CD3+CD4+ lymphocytes [52].

Kohler et al., has described the $\lg G$ and $\lg A$ antibody response to gluten that is fundamental to celiac disease as a humoral response caused by the activity of B cells, which are upregulated by Th2 cytokines [53]. Recently Corouge et al., have presented evidence that this humoral response in many cases may be associated with a Th2 induced allergy to candida albicans which results in cross reactivity with gluten leading to the development of celiac disease [54].

This data shows that celiac is an allergic disease using the broad definition of allergy and Th2 cell activation plays a significant role in its etiology. So based on the prior section and specifically based on the effect of vitamin $D$ supplementation on Th2 cytokines it would seem that large doses of vitamin D among the young could be a risk factor for inducing celiac disease as well.

Ress et al., has found that celiac is about four times more common among children with atopic dermatitis [55]. Ludvigsson et al., has found that asthma is about 1.6 times more common among those with celiac [56]. The comorbidity with celiac of both of these allergic diseases suggests the possibility of a common underlying risk factor. As previously noted oral vitamin $D$ supplementation among the young has been found to be a risk factor for inducing both atopic dermatitis and asthma based on the work of Hypponen et al., and Back et al., among others [33,35]. So the high comorbidity with celiac also suggests the possibility that oral vitamin $D$ supplementation among the young could be a risk factor in inducing it as well.

\section{Williams syndrome}

Williams syndrome is a genetic syndrome that features hypercalcemia, short stature, narrowing of the blood vessels of the heart, modest deficits of intelligence, and sometimes autism [57]. It is typically caused by a deletion of part of chromosome 7 including the WSTF gene. This results in spikes in 1,25-dihydroxy vitamin $D$ in the blood which cause the hypercalcemia [58]. Given background on vitamin D and allergic disease from a prior section, it should not be surprising that Annaz et al., in a survey on Williams syndrome patients found that asthma and allergies are often comorbid with it as well [59]. Williams syndrome also features high comorbidity with celiac disease. Giannotti et al., found in a cohort of Italian patients with Williams syndrome that $9.5 \%$ tested positive for celiac compared to $0.54 \%$ of controls [60]. As a defining characteristic of Williams syndrome is its spikes in 1,25-dihydroxy vitamin D in the blood, this supports the possibility that such spikes in vitamin $D$ metabolites may be a risk factor for celiac disease as well. As consumption of large doses of vitamin D may increase levels of vitamin D metabolites in the blood, this further suggests that consumption of large doses of vitamin D among the young could be a risk factor in inducing celiac disease.

\section{Epidemiology of celiac disease and vitamin D United States}

Murray et al., found that the prevalence of celiac disease had increased substantially between the 1950s and the year 2000 based on a cohort from Olmsted County, Minnesota. In addition Murray et al., found that much of the increase occurred in recent decades [3]. Some of this increase could 
be explained by increased detection of celiac in the population. However, using historically collected blood samples from the army between 1948 and 1954 and comparing them to blood samples collected between 2006 and 2008 also in Olmsted County, Rubio-Tapia et al., found that the incidence of undiagnosed celiac disease had increased by a factor of four [61]. In other words, while the rate of diagnosis of celiac disease has increased substantially, the percent of the population that has celiac and remain undiagnosed has also increased substantially. So there has been a true increase in the prevalence of celiac disease. Using the same Minnesota population Ludvigsson et al., has found that the incidence of celiac has continued increasing through 2010. Specifically, between 2000 and 2010 there was about a $70 \%$ increase in the incidence [4]. A recent study based on serological testing of a mostly adult population estimated prevalence of celiac in the United States at 1 in 113 [62].

Since the 1930 s vitamin D supplementation of milk has been common in the United States [63]. As noted in a prior section most infants and toddlers receive large amounts of oral vitamin $D$ through fortification and supplementation. However, this is primarily a modern phenomenon.

Here are some key events with dates that have pushed consumption of oral vitamin D among the young in the United States to high levels:

1. 1968: Flintstones, the first children's multivitamin to develop a significant market were introduced. Flintstones vitamins were fortified with $400 \mathrm{IU}$ of vitamin D during the 1980s and 1990s and are now fortified with $600 \mathrm{IU}$ of vitamin D [23,64-66].

2. 1980: The Infant Formula Act required all infant formula to include at least $40 \mathrm{IU} / 100 \mathrm{Kcal}$ (about $280 \mathrm{IU}$ per liter) of vitamin $D$ [67]. It also established penalties for manufacturers who do not meet the minimum level. Zhou et al., among others has observed that it created incentives for over-fortification [68] and indeed testing since the passage of the act has found that infant formula is typically significantly over-fortified relative to what the act required [20].

3. June 1992: American Academy of Pediatrics Committee on Nutrition published a recommendation that all nonbreast fed infants be fed formula through 12 months of age [69]. This increased the amount of formula consumed [70].

4. December 1992: Due to vitamin D levels in most milk samples being significantly below levels listed on the label, the FDA decreed that vitamin D levels in milk were to be targeted at levels significantly above the label which resulted in much higher levels of fortification of milk $[21,71,72]$.

5. April 2003: American Academy of Pediatrics published guidelines for vitamin D consumption of 200 IU per day starting at 2 months of age for infants who are breastfed [73].

6. November 2008: American Academy of Pediatrics raised the guidelines to $400 \mathrm{IU}$ per day starting at birth further increasing the consumption of vitamin $D$ by those who are breastfed [22].

These data suggest that vitamin $D$ consumption among the young in the United States rose gradually through the 1970s and 1980s and increased dramatically in the 1990s and has continued increasing since. This pattern is very similar to the gradual increase in celiac rates through the 1980 s which preceded much greater increases in celiac prevalence in recent decades. Thus, the trend in vitamin $\mathrm{D}$ consumption by the young in the United States is consistent with the hypothesis that vitamin $\mathrm{D}$ consumption by the young may be a risk factor for celiac disease.

\section{Sweden}

Sweden has very high rates of celiac disease. Myleus et al., found among a group of 12-year olds the rate was 1 in 34 based on serum testing [74]. Sweden did not always have high rates of celiac disease though. In fact researchers date the onset of the celiac disease epidemic in Sweden to 1984 when rates increased significantly [5].

Vitamin D consumption is very high in Sweden. About 75\% of Swedish infants receive vitamin D drops, and Swedish public health recommendations are that they be taken until 6 years of age [75]. As of 2009 among American infants about 16\% received vitamin D drops [76]. In addition Swedish children receive significant amounts of vitamin $D$ through fortified foods including porridge, fortified margarine, milk, and milk cereal drinks [75]. Historically Sweden had not required whole milk and spreads to be fortified with vitamin D, but in 1983 Sweden by law required whole milk, all butter, and all margarine to be fortified with vitamin $D$ [77]. This decision undoubtedly led to a significant increase in consumption of oral vitamin $D$. So if the hypothesis regarding vitamin $D$ and celiac is true one would expect a surge in celiac cases in Sweden starting in 1984 which is exactly what happened.

Interestingly there was a decline in new celiac cases in Sweden in the mid-1990s. Myleus attributed this to earlier introduction of gluten in small amounts during breastfeeding, increased duration of breastfeeding, and decreased gluten content of cereals [5]. More recent research has called into question these explanations as controlled trials in other populations have found that neither the timing of introduction of gluten nor breastfeeding have significant effects on incidence of celiac disease [6]. However in the case of Sweden those who are breastfed received less vitamin $D$ than those who formula fed as both receive vitamin D drops [75] and formula is also fortified with significant doses of vitamin D. In addition cereals which are competing sources of calories are fortified with vitamin D in Sweden [75]. Therefore, in Sweden these steps would have resulted in aggregate in less vitamin $D$ consumed and especially less vitamin $D$ consumed at the time of introduction of gluten. Based on evidence presented previously on allergic disease, it may be inferred 
that the combination of a Th2 skew to the immune system at the time of antigen introduction makes the development of allergy to the antigen more probable. If this is true, then the reduction in the incidence of celiac disease in the mid-1990s coincident to the changes in feeding practices in Sweden is also consistent with the vitamin D hypothesis.

\section{Finland}

Finland has a high prevalence of celiac disease. Kondrashova et al., found that 1 in 107 Karelian children in Finland had celiac disease based on biopsy following serologic testing. Using a serologic definition solely would give a higher estimate of prevalence [78]. Tylavsky et al., found in an examination of vitamin D consumption in Denmark, Finland, Ireland, and Poland that Finland had the greatest per capita vitamin $D$ consumption among the young [79]. In Finland $86 \%$ of infants take vitamin $D$ drops as they are provided by the Finnish Health Service $[\mathbf{8 0}, \mathbf{8 1}]$. In addition cooked cereals, margarine and milk are fortified with vitamin $D$ [80]. So the high prevalence of celiac and high levels of vitamin D consumption in Finland also fit with the hypothesis.

\section{Russia}

The prevalence of celiac disease in Russia is low. Kondrashova's study cited above was designed to measure the difference in celiac prevalence between Russian Karelian and Finnish Karelian children. From this study, the prevalence among Russian Karelians was 1 in 496 based on biopsy following serological testing [78]. This is much lower than the prevalence among Finnish Karelians cited above [78]. Russian food is not fortified with vitamin $D$ and historically there has been little vitamin D supplementation in Russia [82,83]. So consumption of vitamin D among children in Russia is low. So the low vitamin D consumption and low celiac prevalence in Russia also fits the hypothesis.

\section{Germany}

The prevalence of celiac disease in Germany is relatively low. Unfortunately, no recent study in the literature appears to document prevalence among children in Germany. However, Kratzer et al., found that 1 in 270 adults in Germany tested positive for celiac disease based on serology [84]. While there are some exceptions, vitamin D fortification of foods is generally prohibited in Germany [85]. So based on Germany's negligible vitamin $D$ fortification and modest prevalence of celiac, it also fits the hypothesis.

\section{Summary}

The epidemiological data, which are summarized in (Table 1), illustrate that celiac prevalence is highest in countries that have the highest vitamin $D$ consumption among the young and increases in celiac prevalence appear to be associated with increases in vitamin D consumption.

\section{Breastfeeding and celiac}

A number of researchers have looked at the question of whether breastfeeding reduces the risk of celiac disease. Greco et al., using an Italian cohort from the 1980s found that breastfeeding is protective [86]; Ivarsson et al., using a Swedish cohort from the 1990s also found that breastfeeding is protective [87]; yet more recently, Lionetti et al., found in a large randomized trial among genetically at risk Italian infants which began enrolling participants in 2003 that breastfeeding offers no protection against celiac [88]. What could explain these seemingly contradictory results?

Consider the oral vitamin D recommendations in place at the time and location of each of these studies. Swedish public health officials had begun recommending vitamin D drops for all infants independent of whether or not they are breastfed starting in 1978 [75]. Italian physicians began recommending vitamin $D$ drops be given to breastfed babies starting around 1995 [89].

If the hypothesis regarding vitamin $D$ being a risk factor for celiac were true, what would one expect from the study results? Few if any of the Italian children in Greco's study would have received vitamin $D$ drops as it predated recommendations regarding supplementation in Italy. As infant formula is fortified with vitamin $D$, those receiving infant formula would have consumed more vitamin D as infants. Hence one would expect them to have had a higher rate of celiac which agrees with what Greco et al., found. The vast majority of the children in Ivarsson's study would have received vitamin D drops based on Swedish recommendations in place at the time. As infant formula is fortified with vitamin $D$ as well those that received it would have received more vitamin $D$ in total than those who were breastfed. Hence those receiving infant formula would

Table 1. Celiac epidemiology and vitamin D consumption.

\begin{tabular}{|c|c|c|c|c|c|c|c|}
\hline \multirow[b]{2}{*}{ Country } & \multirow[b]{2}{*}{ Prevalence } & \multicolumn{3}{|c|}{ Celiac epidemiology } & \multicolumn{3}{|c|}{ Oral vitamin D } \\
\hline & & Population & Testing & Epidemiology & Assessment & Consumption & Comments \\
\hline USA & $1: 113$ & Adults \& Children & Serological & Up in recent decades & High & High & Up in recent decades \\
\hline Sweden & $1: 34$ & Twelve year olds & Serological & Big increase in 1984 & Very high & Very high & Big increase in 1983 \\
\hline Finland & $1: 107$ & Karelian children & Biopsy & -- & High & High & D drops from Health Service \\
\hline Russia & $1: 496$ & Karelian children & Biopsy & -- & Low & Low & No fortification \\
\hline Germany & $1: 270$ & Adults & Serological & -- & Low & Low & No fortification \\
\hline
\end{tabular}


be expected to have a higher rate of celiac which agrees with the results. In Lionetti's study it seems probable that many of the breastfed infants would have received vitamin D drops while formula fed infants would not have based on the Italian recommendations. Hence the vitamin D exposure of these two groups may have been comparable which would have resulted in comparable levels of celiac disease which is what was found. So the hypothesis that vitamin $D$ is a risk factor for celiac of fers a plausible explanation for the seemingly contradictory results regarding breastfeeding and celiac in the literature.

\section{Two counter arguments examined}

A skeptical reader might question whether oral vitamin $D$ could be a risk factor in inducing celiac as a number of cases of vitamin $D$ deficiency have been observed among those with celiac. For example Kemppainen et al., found that the blood level of 25-hydroxy vitamin $D$ in those with celiac were lower on average than in the general population [90]. First the levels of vitamin D in Kemppainen's study were measured in an adult population after the onset of celiac disease. If one looks in younger populations one sees a different result. For example, Villanueva et al., found marginally higher 25-hydroxy vitamin D levels among children with celiac than among controls but the difference seemed to be associated with differences in body mass [91]. Second, Bickle has suggested that elevated 1,25-dihydroxy vitamin $\mathrm{D}$ may be common in celiac disease [92]. Therefore the lower levels of 25-hydroxy vitamin D seen in some adults does not conflict with the hypothesis that significant consumption of oral vitamin D among the young may be a causative factor in inducing celiac disease.

Others might question how oral vitamin $D$ could play a role in inducing celiac disease since celiac disease has significantly greater than average comorbidity with some autoimmune diseases such as type 1 diabetes [93] and evidence suggests that supplementation with vitamin $D$ in the young reduces the risk of type 1 diabetes [94]. First, comorbidity between autoimmune and allergic diseases is not uncommon. For example lupus which is considered an autoimmune disease has high comorbidity with atopic dermatitis, an allergic disease [95]. Similarly the autoimmune disease alopecia areata has high comorbidity with atopic dermatitis [96] and the autoimmune disease Kawasaki disease is often comorbid with allergic diseases as well [97]. So celiac's greater than average comorbidity with certain autoimmune diseases does not preclude it from also being an allergic disease.

Second, comorbidity data suggest that supplementation with vitamin D may have very different effects on celiac disease risk and type 1 diabetes risk. As previously highlighted Ress et al., found that celiac is about four times more prevalent in those with atopic dermatitis [55], but Thomsen et al., found that type 1 diabetes has much less than average comorbidity with atopic dermatitis [98]. In addition the study cited above on type 1 diabetes risk reduction from oral vitamin $D$ relies on the same 1966 Finnish birth cohort data and has the same lead author, Hypponen, as a study cited earlier in this paper that suggests that oral vitamin $D$ in children increases risk of allergic disease $[33,94]$. In other word, if one believes the data on oral vitamin $\mathrm{D}$ supplementation and disease susceptibility derived from the 1966 Finnish birth cohort, and comorbidity with atopic dermatitis is relevant to the determination of risk factors, then the data suggest that celiac and type 1 diabetes should have opposite risk profiles with respect to the effect of vitamin D supplementation. As oral vitamin D supplementation in the young reduces the risk of type 1 diabetes and increases the risk of atopic dermatitis, one would therefore expect it to increase the risk of celiac disease.

\section{Conclusion}

A wealth of evidence supports the hypothesis that significant consumption of oral vitamin D among the young is a risk factor for inducing celiac disease. Exposing infants and toddlers to large doses of oral vitamin $D$ has been found to be a risk factor for inducing allergic diseases including atopic dermatitis and asthma both of which have a high comorbidity with celiac. Celiac is an allergic disease using a broad definition of allergic disease and elevations in Th2 cytokines have been shown to be fundamental to celiac disease. As Th2 cytokines are upregulated by oral vitamin $D$, this suggests that oral vitamin $D$ could be a risk factor in inducing celiac disease as well. The case of Williams syndrome and its spikes in 1,25-dihydroxy vitamin $D$ and high comorbidity with celiac further supports this hypothesis. Epidemiologically, the countries that have the most aggressive fortification and supplementation policies for vitamin $D$ are the countries where the prevalence of celiac is greatest. In addition the increase in supplementation and fortification of vitamin $D$ in recent decades in the United States corresponds with the increasing rates of celiac disease seen in the United States during the same time period. Also the Swedish celiac disease epidemic starting around 1984 corresponds well to implementation of widespread vitamin D fortification in Sweden dating from 1983. Additional research will be needed to confirm this hypothesis.

\section{Competing interests}

The author declares that he has no competing interests.

\section{Acknowledgement}

The author is grateful for the moral support of his family and the assistance of the librarians of the Darien Public Library in tracking down articles.

\section{Publication history}

Editor: Thomas John Brett, Washington University School of Medicine, USA.

Received: 07-Feb-2015 Final Revised: 14-Apr-2015

Accepted: 01-May-2015 Published: 06-May-2015

\section{References}

1. Rewers M. Epidemiology of celiac disease: what are the prevalence, incidence, and progression of celiac disease? Gastroenterology. 2005; 128:S47-51. | Article | PubMed 
2. Reilly NR and Green PH. Epidemiology and clinical presentations of celiac disease. Semin Immunopathol. 2012; 34:473-8. I Article I PubMed

3. Murray JA, Van Dyke C, Plevak MF, Dierkhising RA, Zinsmeister AR and Melton LJ, 3rd. Trends in the identification and clinical features of celiac disease in a North American community, 1950-2001. Clin Gastroenterol Hepatol. 2003; 1:19-27. | Article | PubMed

4. Ludvigsson JF, Rubio-Tapia A, van Dyke CT, Melton LJ, 3rd, Zinsmeister AR, Lahr BD and Murray JA. Increasing incidence of celiac disease in a North American population. Am J Gastroenterol. 2013; 108:818-24. | Article | PubMed Abstract | PubMed Full Text

5. Myleus A. Towards Explaining the Swedish Epidemic of Celiac Diseasean epidemiological approach. Department of Public Health and Clinical Medicine, Epidemiology and Global Health. Umea. 2012. I Article

6. Ludvigsson JF and Green PH. The missing environmental factor in celiac disease. N Engl J Med. 2014; 371:1341-3. | Article | PubMed

7. DeLuca HF. Overview of general physiologic features and functions of vitamin D. Am J Clin Nutr. 2004; 80:1689S-96S. I Article I PubMed

8. Green $\mathrm{PH}$. The many faces of celiac disease: clinical presentation of celiac disease in the adult population. Gastroenterology. 2005; 128:S748. | Article | PubMed

9. Pare $P$, Douville $P$, Caron $D$ and Lagace R. Adult celiac sprue: changes in the pattern of clinical recognition. J Clin Gastroenterol. 1988; 10:395400. | Article | PubMed

10. Mavrinac MA, Ohannessian A, Dowling EP and Dowling PT. Why celiac disease is so easy to miss. J Fam Pract. 2014; 63:508-13. | Article | PubMed

11. Chavhan SG, Brar RS, Banga HS, Sandhu HS, Sodhi S, Gadhave PD, Kothule VR and Kammon AM. Clinicopathological Studies on Vitamin D(3) Toxicity and Therapeutic Evaluation of Aloe vera in Rats. Toxicol Int. 2011; 18:35-43. | Article | PubMed Abstract | PubMed Full Text

12. Klontz KC and Acheson DW. Dietary supplement-induced vitamin D intoxication. N Engl J Med. 2007; 357:308-9. | Article | PubMed

13. Jacobus $\mathrm{CH}$, Holick MF, Shao Q,Chen TC, Holm IA, Kolodny JM, Fuleihan GE and Seely EW. Hypervitaminosis D associated with drinking milk. $N$ Engl J Med. 1992; 326:1173-7. | Article | PubMed

14. Crew KD, Xiao T2 and Thomas PS. et al. Safety, Feasibility, and Biomarker Effects of High-Dose Vitamin D Supplementation Among Women at High Risk for Breast Cancer. IJFS. 2015; S1:1-16. | Pdf

15. Laaksi I, Ruohola JP, Mattila V, Auvinen A, Ylikomi T and Pihlajamaki H. Vitamin $D$ supplementation for the prevention of acute respiratory tract infection: a randomized, double-blinded trial among young Finnish men. J Infect Dis. 2010; 202:809-14. | Article | PubMed

16. Dawson-Hughes B, Harris SS, Krall EA and Dallal GE. Effect of calcium and vitamin $\mathrm{D}$ supplementation on bone density in men and women 65 years of age or older. N Engl J Med. 1997; 337:670-6. | Article | PubMed

17. Lehtonen-Veromaa MK, Mottonen TT, Nuotio IO, Irjala KM, Leino AE and Viikari JS. Vitamin D and attainment of peak bone mass among peripubertal Finnish girls: a 3-y prospective study. Am J Clin Nutr. 2002; 76:1446-53. | Article | PubMed

18. Reeve LE, Chesney RW and DeLuca HF. Vitamin D of human milk: identification of biologically active forms. Am J Clin Nutr. 1982; 36:1226. | Article | PubMed

19. Reeve LE, Jorgensen NA and DeLuca HF. Vitamin D compounds in cows' milk. J Nutr. 1982; 112:667-72. | Article | PubMed

20. Pehrsson PR, Lemar LE, Patterson KY and Exler J. Vitamin D and Selected Fatty Acids in U.S. Infant Formulas. USDA. 2008. I Pdf

21. Patterson KY, Phillips KM, Horst RL, Byrdwell WC, Exler J, Lemar LE and Holden JM. Vitamin D content and variability in fluid milks from a US Department of Agriculture nationwide sampling to update values in the National Nutrient Database for Standard Reference. J Dairy Sci. 2010; 93:5082-90. | Article | PubMed

22. Wagner $\mathrm{CL}$ and Greer FR. Prevention of rickets and vitamin D deficiency in infants, children, and adolescents. Pediatrics. 2008; 122:1142-52. | Article | PubMed
23. Does your child's multivitamins have enough vitamin D? Flintstones Complete. 2014. I Pdf

24. 08065, Cereals ready-to-eat, KELLOGG, KELLOGG'S RICE KRISPIES. U.S. Department of Agriculture, Agricultural Research Service. USDA National Nutrient Database for Standard Reference. Release 21. 2008.

25. Moore CE, Murphy MM and Holick MF. Vitamin D intakes by children and adults in the United States differ among ethnic groups. J Nutr. 2005; 135:2478-85. | Article | PubMed

26. Murphy K. Janeway's Immunobiology. New York and London. Garland Science. 2012. I Book

27. Jones AP, Tulic MK, Reuter K and Prescott SL. Vitamin D and Allergic Disease: Sunlight at the End of the Tunnel? Nutrients. 2012; 4:13-28. | Article

28. Litonjua AA. Vitamin D deficiency as a risk factor for childhood allergic disease and asthma. Curr Opin Allergy Clin Immunol. 2012; 12:179-85. Article | PubMed Abstract | PubMed Full Text

29. Wjst M. Is vitamin D supplementation responsible for the allergy pandemic? Curr Opin Allergy Clin Immunol. 2012; 12:257-62. | Article | PubMed

30. Baek JH, Shin YH, Chung IH, Kim HJ, Yoo EG, Yoon JW, Jee HM, Chang YE and Han MY. The link between serum vitamin D level, sensitization to food allergens, and the severity of atopic dermatitis in infancy. $J$ Pediatr. 2014; 165:849-54. | Article | PubMed

31. Heimbeck I, Wjst M and Apfelbacher CJ. Low vitamin D serum level is inversely associated with eczema in children and adolescents in Germany. Allergy. 2013; 68:906-10. | Article | PubMed

32. Kang JW, Kim JH, Yoon JH and $\mathrm{Kim} \mathrm{CH}$. The association between serum vitamin D level and immunoglobulin $\mathrm{E}$ in Korean adolescents. Int J Pediatr Otorhinolaryngol. 2014; 78:817-20. | Article I PubMed

33. Hypponen E, Sovio U, Wjst M, Patel S, Pekkanen J, Hartikainen AL and Jarvelinb MR. Infant vitamin d supplementation and allergic conditions in adulthood: northern Finland birth cohort 1966. Ann N Y Acad Sci. 2004; 1037:84-95. | Article | PubMed

34. Nja F, Nystad W, Lodrup Carlsen KC, Hetlevik O and Carlsen KH. Effects of early intake of fruit or vegetables in relation to later asthma and allergic sensitization in school-age children. Acta Paediatr. 2005; 94:147-54. | Article I PubMed

35. Back O, Blomquist HK, Hernell O and Stenberg B. Does vitamin D intake during infancy promote the development of atopic allergy? Acta Derm Venereol. 2009; 89:28-32. | Article | PubMed

36. Kull I, Bergstrom A, Melen E, Lilja G, van Hage M, Pershagen G and Wickman M. Early-life supplementation of vitamins A and D, in watersoluble form or in peanut oil, and allergic diseases during childhood. $J$ Allergy Clin Immunol. 2006; 118:1299-304. | Article I PubMed

37. Wjst M. Another explanation for the low allergy rate in the rural Alpine foothills. Clin Mol Allergy. 2005; 3:7. | Article | PubMed Abstract | PubMed Full Text

38. Wjst M. Introduction of oral vitamin D supplementation and the rise of the allergy pandemic. Allergy Asthma Clin Immunol. 2009; 5:8. | Article | PubMed Abstract | PubMed Full Text

39. Romagnani S. The Th1/Th2 paradigm. Immunol Today. 1997; 18:263-6. | Article | PubMed

40. Cantorna MT and Mahon BD. Mounting evidence for vitamin D as an environmental factor affecting autoimmune disease prevalence. Exp Biol Med (Maywood). 2004; 229:1136-42. | Article | PubMed

41. Mazzarella G, Bianco A, Catena E, De Palma R and Abbate GF. Th1/Th2 lymphocyte polarization in asthma. Allergy. 2000; 55 Suppl 61:6-9. | Article | PubMed

42. Newell L, Polak ME, Perera J, Owen C, Boyd P, Pickard C, Howarth PH, Healy E, Holloway JW, Friedmann PS and Ardern-Jones MR. Sensitization via healthy skin programs Th2 responses in individuals with atopic dermatitis. J Invest Dermatol. 2013; 133:2372-80. | Article | PubMed

43. Searing DA and Leung DY. Vitamin D in atopic dermatitis, asthma and allergic diseases. Immunol Allergy Clin North Am. 2010; 30:397-409. I Article | PubMed Abstract | PubMed Full Text 
Seth Bittker, Journal of Allergy and Asthma 2015,

44. Hamzaoui A, Berraies A, Hamdi B, Kaabachi W, Ammar J and Hamzaoui $K$. Vitamin $D$ reduces the differentiation and expansion of Th17 cells in young asthmatic children. Immunobiology. 2014; 219:873-9. | Article | PubMed

45. O'Connor BP, Vogel LA, Zhang W, Loo W, Shnider D, Lind EF, Ratliff M, Noelle RJ and Erickson LD. Imprinting the fate of antigen-reactive $B$ cells through the affinity of the B cell receptor. J Immunol. 2006; 177:772332. | Article | PubMed Abstract | PubMed Full Text

46. van der Windt DA, Jellema P, Mulder CJ, Kneepkens CM and van der Horst $\mathrm{HE}$. Diagnostic testing for celiac disease among patients with abdominal symptoms: a systematic review. JAMA. 2010; 303:1738-46. | Article | PubMed Abstract | PubMed Full Text

47. Allergy. Dorland's Illustrated Medical Dictionary. 32 ${ }^{\text {nd }}$ ed. 2011. |Book

48. Dietert RR and Zelikoff JT. Early-life environment, developmental immunotoxicology, and the risk of pediatric allergic disease including asthma. Birth Defects Res B Dev Reprod Toxicol. 2008; 83:547-60. | Article I PubMed

49. Lahat N, Shapiro S, Karban A, Gerstein R, Kinarty A and Lerner A. Cytokine profile in coeliac disease. Scand J Immunol. 1999; 49:441-6. I Article | PubMed

50. Manavalan JS, Hernandez L, Shah JG, Konikkara J, Naiyer AJ, Lee AR, Ciaccio E, Minaya MT, Green PH and Bhagat G. Serum cytokine elevations in celiac disease: association with disease presentation. Hum Immunol. 2010; 71:50-7. | Article | PubMed

51. Chowers Y, Marsh MN, De Grandpre L, Nyberg A, Theofilopoulos AN and Kagnoff MF. Increased proinflammatory cytokine gene expression in the colonic mucosa of coeliac disease patients in the early period after gluten challenge. Clin Exp Immunol. 1997; 107:141-7. | Article I PubMed Abstract | PubMed Full Text

52. Mastrandrea F, Semeraro FP, Coradduzza G, Manelli M, Scarcia G, Pezzuto $F$ and Serio G. CD34+ hemopoietic precursor and stem cells traffic in peripheral blood of celiac patients is significantly increased but not directly related to epithelial damage severity. Eur Ann Allergy Clin Immunol. 2008; 40:90-103. | PubMed

53. Koehler P, Wieser H and Konitzer K. Celiac Disease and Gluten: Multidisciplinary Challenges and Opportunities. Elsevier London. 2014; 70.

54. Corouge M, Loridant S, Fradin C, Salleron J, Damiens S, Moragues MD, Souplet V, Jouault T, Robert R, Dubucquoi S, Sendid B, Colombel JF and Poulain D. Humoral Immunity Links Candida albicans Infection and Celiac Disease. PLoS One. 2015; 10:e0121776. | Article | PubMed Abstract I PubMed Full Text

55. Ress K, Annus T, Putnik U, Luts K, Uibo R and Uibo O. Celiac disease in children with atopic dermatitis. Pediatr Dermatol. 2014; 31:483-8. Article | PubMed

56. Ludvigsson JF, Hemminki K, Wahlstrom J and Almqvist C. Celiac disease confers a 1.6-fold increased risk of asthma: a nationwide populationbased cohort study. J Allergy Clin Immunol. 2011; 127:1071-3. | Article I PubMed

57. Aitken KJ. A-Z of Genetic Factors in Autism. Jessica Kingsley Publishers. London. 2010; 361-366.

58. Barnett $C$ and Krebs JE. WSTF does it all: a multifunctional protein in transcription, repair, and replication. Biochem Cell Biol. 2011; 89:12-23. | Article | PubMed Abstract | PubMed Full Text

59. Annaz D, Hill CM, Ashworth A, Holley S and Karmiloff-Smith A. Characterisation of sleep problems in children with Williams syndrome. Res Dev Disabil. 2011; 32:164-9. | Article | PubMed

60. Giannotti A, Tiberio G, Castro M, Virgilii F, Colistro F, Ferretti F, Digilio MC, Gambarara M and Dallapiccola B. Coeliac disease in Williams syndrome. J Med Genet. 2001; 38:767-8. | Article I PubMed Abstract I PubMed Full Text

61. Rubio-Tapia A, Kyle RA, Kaplan EL, Johnson DR, Page W, Erdtmann F, Brantner TL, Kim WR, Phelps TK, Lahr BD, Zinsmeister AR, Melton LJ, 3rd and Murray JA. Increased prevalence and mortality in undiagnosed celiac disease. Gastroenterology. 2009; 137:88-93. | Article I PubMed Abstract | PubMed Full Text
62. Katz KD, Rashtak S, Lahr BD, Melton LJ, 3rd, Krause PK, Maggi K, Talley NJ and Murray JA. Screening for celiac disease in a North American population: sequential serology and gastrointestinal symptoms. Am J Gastroenterol. 2011; 106:1333-9. I Article I PubMed Abstract I PubMed Full Text

63. Schwab B. Nutrition, Education and Development: The Case of Vitamin D Milk. 2011. | Article

64. Flintstones Vitamins. 2014. I Website

65. Issenman RM, Slack R, MacDonald L and Taylor W. Children's multiple vitamins: overuse leads to overdose. Can Med Assoc J. 1985; 132:781-4. | PubMed Abstract | PubMed Full Text

66. Flintstones vitamins. 1999. | Website

67. Newberry RE. The Infant Formula Act of 1980. J Assoc Off Anal Chem. 1982; 65:1472-3. | Article | PubMed

68. Zhou SS, Zhou YM, Li D and Ma Q. Early infant exposure to excess multivitamin: a risk factor for autism? Autism Res Treat. 2013; 2013:963697. | Article | PubMed Abstract | PubMed Full Text

69. Committee on Nutrition, American Academy of Pediatrics. The use of whole cow's milk in infancy. Pediatrics. 1992; 89:1105-1109. | Pdf

70. Fomon S. Infant feeding in the 20th century: formula and beikost. $J$ Nutr. 2001; 131:409S-20S. | Article | PubMed

71. Holick MF, Shao Q, Liu WW and Chen TC. The vitamin D content of fortified milk and infant formula. N Engl J Med. 1992; 326:1178-81. | Article | PubMed

72. M-I-92-13: Recommended Levels of Vitamins A \& D in Milk Products Food and Drug Administration. 1992. I Website

73. Gartner LM and Greer FR. Prevention of rickets and vitamin D deficiency: new guidelines for vitamin D intake. Pediatrics. 2003; 111:908-10. | Article | PubMed

74. Myleus A, Ivarsson A, Webb C, Danielsson L, Hernell O, Hogberg L, Karlsson E, Lagerqvist C, Norstrom F, Rosen A, Sandstrom O, Stenhammar $\mathrm{L}$, Stenlund $\mathrm{H}$, Wall $\mathrm{S}$ and Carlsson A. Celiac disease revealed in $3 \%$ of Swedish 12-year-olds born during an epidemic. J Pediatr Gastroenterol Nutr. 2009; 49:170-6. | Article | PubMed

75. Blomquist HK, Frangsmyr A, Hernell O, Stenberg B and Back O. Dietary intake of vitamin D during the second half of infancy in Swedish infants. Scandinavian Journal of Nutrition. 2004; 48:173-177. | Article

76. Taylor JA, Geyer LJ and Feldman KW. Use of supplemental vitamin d among infants breastfed for prolonged periods. Pediatrics. 2010 125:105-11. | Article | PubMed

77. Livsmedelsveket. 2014. | Website

78. Kondrashova A, Mustalahti K, Kaukinen K, Viskari H, Volodicheva V, Haapala AM, Ilonen J, Knip M, Maki M and Hyoty H. Lower economic status and inferior hygienic environment may protect against celiac disease. Ann Med. 2008; 40:223-31. | Article | PubMed

79. Tylavsky FA, Cheng S, Lyytikainen A, Viljakainen $\mathrm{H}$ and Lamberg-Allardt $\mathrm{C}$. Strategies to improve vitamin D status in northern European children: exploring the merits of vitamin D fortification and supplementation. J Nutr. 2006; 136:1130-4. | Article | PubMed

80. Kyttala P, Erkkola M, Kronberg-Kippila C, Tapanainen H, Veijola R, Simell $\mathrm{O}$, Knip $\mathrm{M}$ and Virtanen SM. Food consumption and nutrient intake in Finnish 1-6-year-old children. Public Health Nutr. 2010; 13:947-56. | Article | PubMed

81. Laaksi IT, Ruohola JP, Ylikomi TJ, Auvinen A, Haataja RI, Pihlajamak HK and Tuohimaa PJ. Vitamin D fortification as public health policy: significant improvement in vitamin D status in young Finnish men. Eur J Clin Nutr. 2006; 60:1035-8. | Article | PubMed

82. Kodentsova VM, Vrzhesinskaia OA and Sokol'nikov AA. Food fortified with vitamins: the history and perspectives. Vopr Pitan. 2012; 81:66-78. I PubMed

83. Bakhtiyarova S, Lesnyak O, Kyznesova N, Blankenstein MA and Lips P. Vitamin D status among patients with hip fracture and elderly control subjects in Yekaterinburg, Russia. Osteoporos Int. 2006; 17:441-6. Article | PubMed

84. Kratzer W, Kibele M, Akinli A, Porzner M, Boehm BO, Koenig W, Oeztuerk 
Seth Bittker, Journal of Allergy and Asthma 2015,

http://www.hoajonline.com/journals/pdf/2054-9873-2-2.pdf

S, Mason RA, Mao R and Haenle MH. Prevalence of celiac disease in Germany: a prospective follow-up study. World J Gastroenterol. 2013; 19:2612-20. | Article | PubMed Abstract | PubMed Full Text

85. Brown J, Sandmann A, Ignatius A, Amling $M$ and Barvencik F. New perspectives on vitamin $D$ food fortification based on a modeling of 25(OH)D concentrations. Nutr J. 2013; 12:151. | Article | PubMed Abstract | PubMed Full Text

86. Greco L, Auricchio S, Mayer M and Grimaldi M. Case control study on nutritional risk factors in celiac disease. J Pediatr Gastroenterol Nutr. 1988; 7:395-9. I PubMed

87. Ivarsson A, Hernell O, Stenlund $\mathrm{H}$ and Persson LA. Breast-feeding protects against celiac disease. Am J Clin Nutr. 2002; 75:914-21. I Article I PubMed

88. Lionetti E, Castellaneta S, Francavilla R, Pulvirenti A, Tonutti E, Amarri S, Barbato M, Barbera C, Barera G, Bellantoni A, Castellano E, Guariso G, Limongelli MG, Pellegrino S, Polloni C, Ughi C, Zuin G, Fasano A and Catassi C. Introduction of gluten, HLA status, and the risk of celiac disease in children. N Engl J Med. 2014; 371:1295-303. | Article | PubMed

89. Saggese $G$ and Igli Baroncelli G. Nutritional aspects of calcium and vitamin D from infancy to adolescence. Ann Ist Super Sanita. 1995; 31:461-79. | PubMed

90. Kemppainen T, Kroger H, Janatuinen E, Arnala I, Kosma VM, Pikkarainen P, Julkunen R, Jurvelin J, Alhava E and Uusitupa M. Osteoporosis in adult patients with celiac disease. Bone. 1999; 24:249-55. | $\underline{\text { Article | PubMed }}$

91. Villanueva J, Maranda $L$ and Nwosu BU. Is vitamin D deficiency a feature of pediatric celiac disease? J Pediatr Endocrinol Metab. 2012; 25:607-10. I PubMed

92. Bikle DD. Vitamin D insufficiency/deficiency in gastrointestinal disorders. J Bone Miner Res. 2007; 22 Suppl 2:V50-4. | Article I PubMed

93. Adlercreutz EH, Svensson J, Hansen D, Buschard K, Lernmark A, Mortensen $\mathrm{HB}$ and Agardh D. Prevalence of celiac disease autoimmunity in children with type 1 diabetes: regional variations across the Oresund strait between Denmark and southernmost Sweden. Pediatr Diabetes. 2014. | Article | PubMed

94. Hypponen E, Laara E, Reunanen A, Jarvelin MR and Virtanen SM. Intake of vitamin $\mathrm{D}$ and risk of type 1 diabetes: a birth-cohort study. Lancet. 2001; 358:1500-3. | Article I PubMed

95. Wu LC, Hwang CY, Chung PI, Hua TC, Chen YD, Chu SY, Lee DD, Chang YT, Wang WJ, Liu HN and Chen CC. Autoimmune disease comorbidities in patients with atopic dermatitis: a nationwide case-control study in Taiwan. Pediatr Allergy Immunol. 2014; 25:586-92. I Article I PubMed

96. Chu SY, Chen YJ, Tseng WC, Lin MW, Chen TJ, Hwang CY, Chen CC, Lee DD, Chang YT, Wang WJ and Liu HN. Comorbidity profiles among patients with alopecia areata: the importance of onset age, a nationwide population-based study. J Am Acad Dermatol. 2011; 65:949-56. Article I PubMed

97. Wei CC, Lin CL, Kao CH, Liao YH, Shen TC, Tsai JD, Chang YJ and Li TC. Increased risk of Kawasaki disease in children with common allergic diseases. Ann Epidemiol. 2014; 24:340-3. I Article I PubMed

98. Thomsen SF, Duffy DL, Kyvik KO, Skytthe A and Backer V. Relationship between type 1 diabetes and atopic diseases in a twin population. Allergy. 2011; 66:645-7. | Article | PubMed

\section{Citation:}

Bittker S. Exposure to excessive oral vitamin D in youth: a risk factor for celiac disease in later life? J Allergy Asthma. 2015; 2:2.

http://dx.doi.org/10.7243/2054-9873-2-2 